\title{
APLIKASI ANDROID HYBRID UNTUK PEMILIHAN LOKASI KULINER
}

\author{
Vidya Noer Firdausy'), Fahrul Agus ${ }^{2)}$, Indah Fitri Astuti ${ }^{3)}$ \\ ${ }^{1)}$ Program Studi Ilmu Komputer, Fakultas Ilmu Komputer dan Teknologi Informasi, Universitas Mulawarman \\ Jalan Barong Tongkok Kampus Gunung Kelua Samarinda, Telp. (0541)-741118, Kalimantan Timur \\ E-Mail : fahrulagus@unmul.ac.id ${ }^{1,2)}$, indahfitriastuti@yahoo.com ${ }^{3)}$
}

\begin{abstract}
ABSTRAK
Bisnis kuliner saat ini berkembang dengan pesat, seiring dengan perkembangan sosial media dan peningkatan jumlah permintaan konsumen. Selain itu dipicu oleh kemudahan dalam membagikan informasi yang dimanfaatkan pelaku bisnis kuliner untuk mempromosikan mereknya. Penelitian ini bertujuan untuk menerapkan metode Simple Additive Weighting (SAW) dan Sistem Informasi Geografis dalam sebuah aplikasi berbasis Android Hybrid. Metode SAW dipilih karena kemudahan dalam penerapan dan digunakan untuk menghasilkan rekomendasi rumah makan yang diberikan kepada pengguna sebagai referensi untuk memilih rumah makan. Hasil output sistem berupa lima opsi rumah makan terbaik dengan visualisasi peta dari Google Maps. Google Maps juga berperan dalam perhitungan jarak dari lokasi pengguna ke lokasi rumah makan. Sistem ini juga dikembangkan berbasis Android hybrid dengan menggunakan framework PhoneGap.
\end{abstract}

Kata Kunci : rumah makan, sistem penunjang keputusan, simple addtive weighting, google maps, mobile, android, hybrid.

\section{PENDAHULUAN}

Bisnis kuliner saat ini berkembang dengan beragam menu andalan, jenis makanan, harga, dan fasilitas. Hal ini dapat menimbulkan masalah bagi konsumen yang ingin mecoba suatu rumah makan, misalnya jenis makanan khas Jepang, terdapat perbedaan harga signifikan pada rumah makan Kedai Dimsum yang lebih murah dari pada X.O Suki. Hal inilah yang menjadi salah satu faktor yang membuat sebagian masyarakat ragu untuk mencoba atau memilih tempat makan yang sesuai dengan harga, cita rasa, kapasitas dan jarak tempuh yang diinginkan.

Permasalahan ini mendorong pemanfaatan teknologi internet sebagai media untuk mendapatkan informasi rumah makan. Informasi ini memang dapat berasal dari pencarian Google ataupun media sosial seperti Path, Facebook, Twitter, dan Instagram, namun pencarian seperti ini akan sangat merepotkan.

Masyarakat memerlukan media yang lebih efisien yang dapat mengumpulkan informasi khusus rumah makan serta dapat memberikan rekomendasi rumah makan yang sesuai dengan kriteria yang diinginkan. Pemanfaatan sistem pendukung keputusan sebagai salah satu sistem cerdas terkomputerisasi dapat digunakan untuk membantu mengambil keputusan dengan cepat, tepat dan konsisten serta memberikan informasi mengenai rumah makan yang menjadi keluaran sistem.

Banyak metode yang dapat digunakan dalam mengembangkan sistem pendukung keputusan, salah satunya metode Simple Additive Weighting
(SAW) yang sesuai untuk proses pengambilan keputusan karena dapat menentukan nilai bobot untuk setiap kriteria. Sistem Pendukung Keputusan dapat diterapkan di berbagai media seperti desktop, web, dan mobile..

IBM pada situs resminya mengatakan bahwa 7 triliun populasi di dunia, 6 triliun memiliki mobile phone Hal inilah yang menggeser perkembangan teknologi dari yang sebelumnya dikembangkan berbasis web kini lebih diutamakan pengembangan aplikasi berbasis mobile, contohnya seperti sosial media Path dan Instagram yang dikhususkan untuk pengguna smartphone dan membatasi fitur penggunaan pada web. Pengembangan sistem berbasis mobile akan lebih memudahkan masyarakat dalam mencari informasi dan mendapatkan rekomendasi rumah makan karena mudah dibawa dan dioperasikan membuat berbagi informasi menjadi lebih nyaman. Salah satu sistem operasi mobile yang banyak digunakan adalah Android. Banyak vendor smartphone yang menggunakan sistem operasi Android seperti Samsung, Sony, LG, Lenovo, dan Xiomi, selain itu Android merupakan sistem oprasi open source yang menjadikannya mudah dan bebas untuk dikembangkan. Android merupakan aplikasi native, untuk mengembangkan sistem berbasis Android menggunakan tekonologi web dapat memanfaatkan teknologi hybrid. Hybrid application merupakan teknologi menggabungkan aplikasi native dan teknologi web, hal ini membuat programmer dapat mengembangkan aplikasi mobile dengan bahasa dasar PHP, HTML, CSS, dan JavaScript. 


\section{TINJAUAN PUSTAKA}

\subsection{Sistem Pendukung Keputusan}

Definisi konsep Sistem Pendukung pertama diungkapkan pada 1970 oleh Scott Morton dengan istilah "Manajemen Keputusan Sistem", berarti sistem berdasarkan komputerisasi yang dapat membantu membuat keputusan menggunakan data dan model untuk memecahkan masalah yang tidak terstruktur [6].

Sistem Pendukung Keputusan adalah sistem informasi berbasis komputerisasi, untuk menghasilkan alternatif tertentu keputusan untuk membantu sisi tertentu tentang menangani masalah data yang digunakan dan model. Sistem Pendukung Keputusan hanya menyediakan alternatif keputusan, sedangkan keputusan akhir masih ditentukan oleh pengambil keputusan. Sistem Pendukung Keputusan terintegrasi recources intelektual pribadi dan kemampuan komputer untuk meningkatkan kualitas keputusan [1].

Sistem pendukung keputusan umumnya dibangun untuk mendukung solusi dari masalah atau untuk mengevaluasi kesempatan. DSS dimaksudkan untuk mendukung manajemen dalam kerja analitis tampil dengan situasi yang tidak terstruktur dan kriteria jelas [3].

\subsection{Simple Additive Weighting (SAW)}

Salah satu metode penyelesaian masalah MADM adalah dengan menggunakan metode Simple Additive Weighting (SAW). Metode SAW sering juga dikenal istilah metode penjumlahan terbobot. Konsep dasar metode SAW adalah mencari penjumlahan terbobot dari rating kinerja pada setiap alternatif dari semua atribut [2]. Metode SAW membutuhkan proses normalisasi matriks keputusan (X) ke suatu skala yang dapat diperbandingkan dengan semua rating alternatif yang ada [4]. Diberikan persamaan (1):

$$
\mathrm{R}_{\mathrm{ij}}\left\{\begin{array}{cl}
\frac{\mathrm{X}_{\mathrm{ij}}}{\operatorname{Max} \mathrm{X}_{\mathrm{ij}}} & \text { if } j=\text { benefit } \\
\frac{\operatorname{Min} \mathrm{X}_{\mathrm{ij}}}{\mathrm{X}_{\mathrm{ij}}} & \text { if } j=\text { cost }
\end{array}\right.
$$

Dimana $\mathrm{r}_{\mathrm{ij}}$ adalah rating kinerja ternormalisasi dari alternatif $A_{i}$ pada atribut $C_{j} ; i=1,2, \ldots, m$ dan $\mathrm{j}=1,2, \ldots, \mathrm{n}$. Nilai preferensi untuk setiap alternatif $\left(\mathrm{V}_{\mathrm{i}}\right)$ diberikan persamaan (2):

$$
\mathrm{V}_{\mathrm{i}}=\underset{\mathrm{j}=1}{\mathrm{n}} \mathrm{w}_{\mathrm{j}} \mathrm{r}_{\mathrm{ij}}
$$

Dimana $\mathrm{W}_{\mathrm{j}}$ bobot dari setiap kriteria. Nilai $\mathrm{V}_{\mathrm{i}}$ yang paling besar merupakan opsi terbaik untuk memilih rumah makan.

\subsection{Google Maps API}

Google Map adalah layanan aplikasi dan teknologi peta berbasis web yang disediakan oleh
Google secara gartis (bukan untuk kepentingan komersial), temasuk di dalamnya website Google Map (http://maps.google.com), Google Ride Finder, Google Transit, dan peta yang dapat disisipkan pada website lain melalui Google Maps API. Saat ini Google Map adalah layanan pemetaan berbasis web yang populer. Kita dapat menambahkan layanan Google Map ke website kita sendiri menggunakan Google Maps API. Google Maps API dapat ditambahkan ke website kita menggunakan JavaScript. API tersebut menyediakan banyak fasilitas dan utilitas untuk memanipulasi peta dan menambahkan konten ke peta melalui berbagai layanan, memungkinkan Anda untuk membuat aplikasi peta yang kuat pada website Anda.

Pengetahuan yang diperlukan untuk mengembangkan Google Maps API adalah tentang HTML dan JavaScript, sedangkan peta sudah disediakan oleh Google. Jadi kita hanya berkonsentrasi tentang data dan biarkan urusan peta ditangani oleh Google, sehingga dapat menghemat waktu. Fitur yang terdapat dalam Google Maps API, antara lain:

1. Menampilkan Peta Sederhana

Google Maps API memungkinkan pengguna menampilkan peta sederhana pada situs web atau aplikasi mobile.

2. Marker

Marker berguna untuk memberikan petunjuk pada lokasi tertentu. Secara default, marker menggunakan gambar standar. Marker dapat menampilkan icon. Marker dirancang agar dapat interaktif dengan pengguna, misalnya dengan menambahkan animasi seperti bounce. Marker secara default dapat ditekan dan menampilkan infobox yang menampikan informasi mengenai lokasi tersebut. Marker juga memungkinkan untuk dipindahkan dari satu lokasi ke lokasi lain dengan cara mengubah setting draggable menjadi true.

3. Info Windows

Sebuah Info windows menampilkan konten (biasanya teks atau gambar) di jendela pop-up di atas peta, pada lokasi tertentu.

Info windows biasanya berbentuk kotak dialog yang ujungnya berada pada titik koordinat lokasi yang ditentukan. Biasanya info widows ditampilkan ketika marker ditekan, tetapi dapat juga langsung dilampirkan pada lokasi tertentu.

4. Direction

Direction adalah fitur Google Maps API yang memungkinkan pengguna dapat mengetahui arah atau rute dari titik koordinat lokasi awal menuju lokasi yang dituju. Lokasi awal dan lokasi tujuan pada direction dapat diubah atau dragable, dengan mengubah setting dragable menjadi true. Source code JavaScript untuk menampilkan direction dapat dilihat pada gambar 1. 


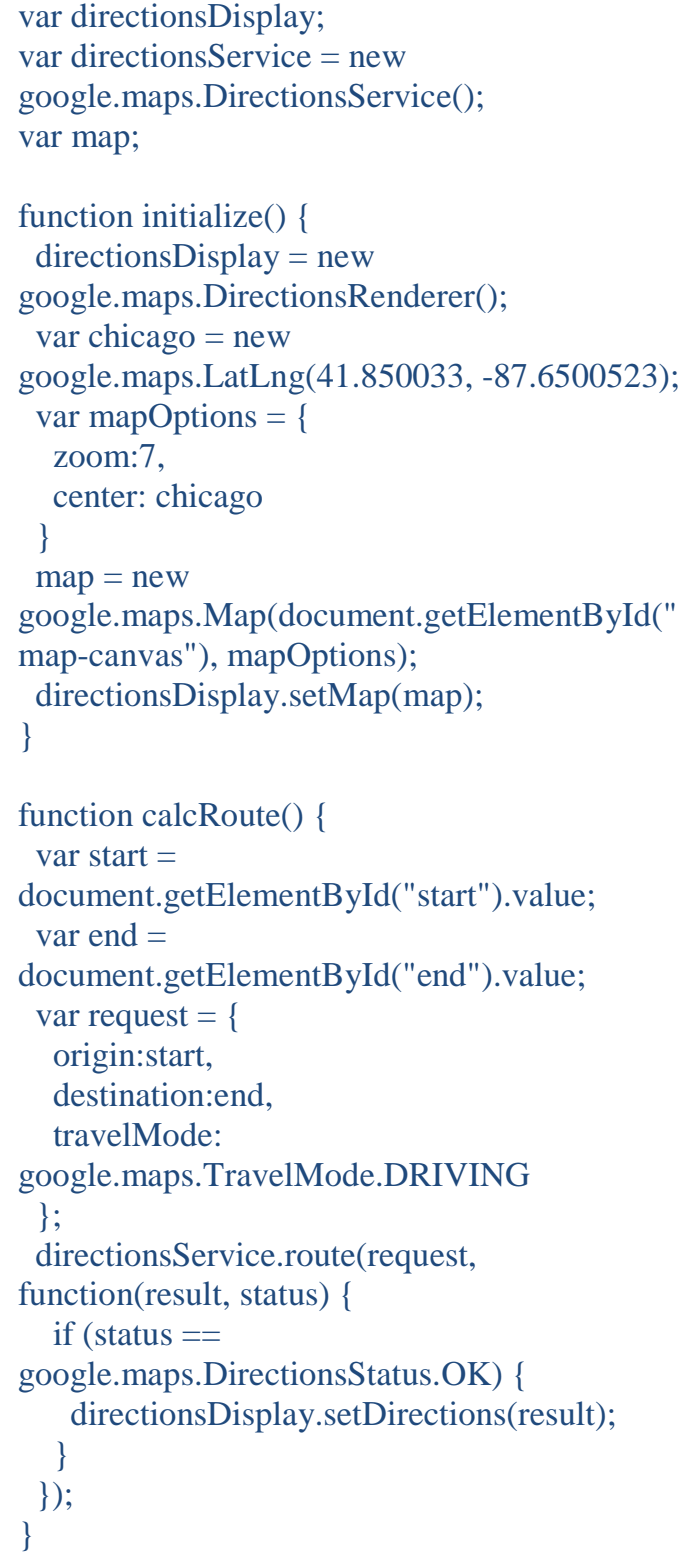

Gambar 1. Source Code Menampilkan Direction

\section{Geolocation}

Geolocation adalah fitur Google Maps API yang memungkinkan pengguna mengetahui koordinat lokasi pengguna. Source code geolocation dapat dilihat pada gambar 2 .

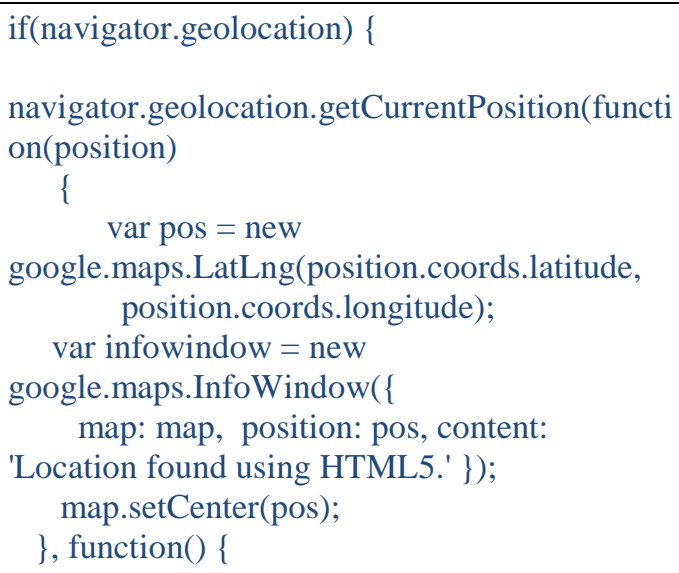

handleNoGeolocation(true);

\}$)$;

\} else \{

// Browser doesn't support Geolocation handleNoGeolocation(false);

\})

Gambar 2. Source Code Geolocation

\section{Matriks Jarak}

Matriks jarak adalah fitur Google Maps API untuk mengetahui jarak dari lokasi satu ke lokasi lainnya. Source code untuk matriks jarak dapat dilihat pada gambar 3 .

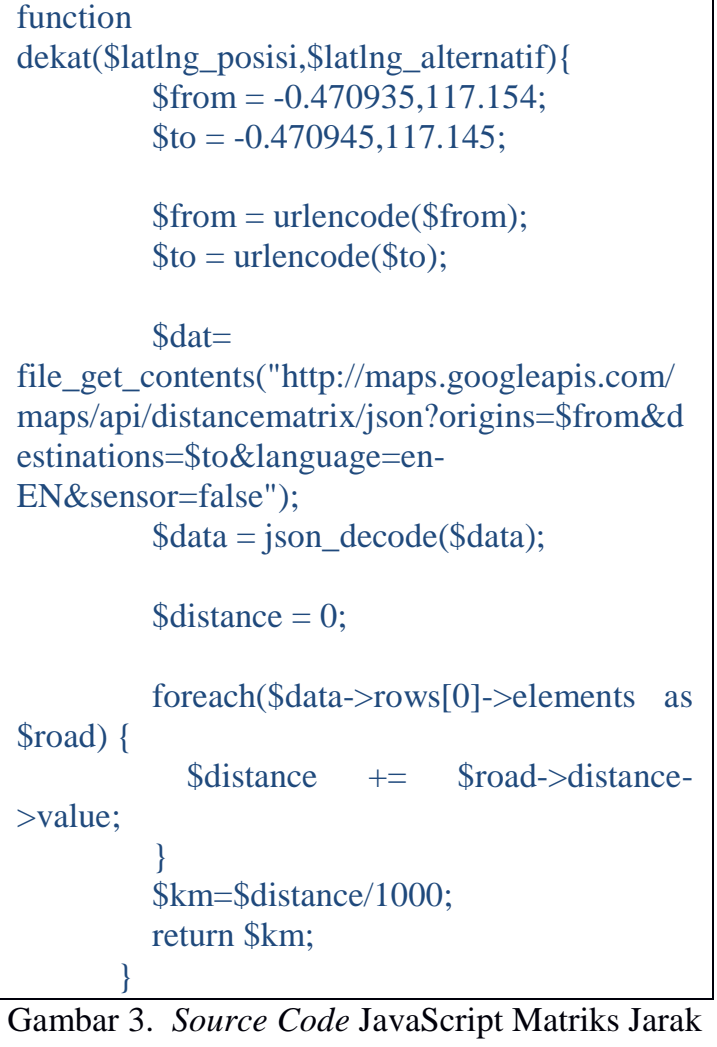

Gambar 3. Source Code JavaScript Matriks Jarak

\subsection{Hybrid Application}

Hybrid application adalah teknologi menggabungkan dua bahasa pemrograman atau dua teknologi menjadi satu, dengan adanya teknologi ini akan memperingan perkerjaan developer dalam mengembangkan aplikasinya ke segala jenis sistem operasi smartphone.

"Hybrid mobile app development combines both native development and web technology, but hybrid apps look and behave much more like web apps than mobile apps" [5].

Menurut Tun, hybrid application menggabungkan aplikasi native dan teknologi web, dengan menggunakan pendekatan ini, programmer dapat membuat aplikasi mobile dengan mengandalkan kemampuan progamming web, namun hybrid application akan tetap terlihat seperti aplikasi web daripada aplikasi mobile.

Pendekatan ini juga menghadirkan library terbuka siap pakai seperti PhoneGap yang menyediakan antarmuka dengan bahasa 


\section{ISSN 1858-4853}

pemrograman JavaScript yang memberikan akses untuk fitur sistem operasi yang mendasarinya. Asitektur sistem hybrid dapat dilihat pada gambar 4.

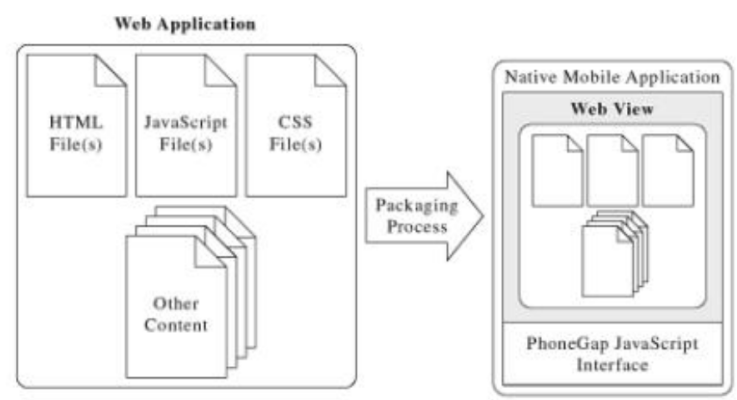

Gambar 4. Asitektur sistem hybrid [7]

\section{HASIL DAN PEMBAHASAN}

\subsection{Perancangan Data}

Metode SAW dapat memecahkan masalah dengan multi-kriteria, yang berarti pemelihan restoran dapat diselesaikan dengan metode SAW. SAW menggunakan bobot setiap kriteria yang berasal dari input data pengguna dan nilai kriteria setiap alternatif yang digunakan untuk mendapatkan alternatif terbaik.

Kriteria yang digunakan untuk menghasilkan alternatif dalam sistem pendukung keputusan terdiri dari:

1. Harga $(\mathrm{C} 1)$

2. Rating $(\mathrm{C} 2)$

3. Kapasitas (C3)

4. Jarak (C4) Tabel 1.

Daftar alternatif restoran dapat dilihat pada

Tabel 1. Daftar Alternatif Restoran

\begin{tabular}{|c|l|c|}
\hline No. & \multicolumn{1}{|c|}{ Nama Restoran } & Alternatif \\
\hline 1. & 2ndfloor Coffee Shop & A1 \\
\hline 2. & Ariza Café & A2 \\
\hline 3. & $\begin{array}{l}\text { Anima Espresso Bar and } \\
\text { Kitchen }\end{array}$ & A3 \\
\hline 4. & Ayam Bakar Wong Solo & A4 \\
\hline 5. & Angkringan Mastumin & A5 \\
\hline 6. & Bakso Gersik & A6 \\
\hline 7. & Balarea Kapedok & A7 \\
\hline 8. & Barvity & A8 \\
\hline 9. & $\begin{array}{l}\text { Bebek \& Ayam Goreng Sari } \\
\text { Rasa "Pak Ndut" }\end{array}$ \\
\hline 10. & BEMO & A10 \\
\hline 11. & BOS Steak \& Ribs & A11 \\
\hline 12. & D'Beranda & A12 \\
\hline 13. & D'Orange & A13 \\
\hline 14. & Double Dipps & A14 \\
\hline 15. & Godhong Gedhang & A16 \\
\hline 16. & Kedai Dimsum & \\
\hline 17. & Kedai Kopi Nusantara & A17 \\
\hline & & \\
\hline
\end{tabular}

\begin{tabular}{|c|l|c|}
\hline 18. & Kedai Sabindo & A18 \\
\hline 19. & Mie Jogja Pak Karso & A19 \\
\hline 20. & Mie Sedap Sari 2 & A20 \\
\hline 21. & Padang Upik & A21 \\
\hline 22. & Pan \& Flip & A22 \\
\hline 23. & Solaria & A23 \\
\hline 24. & Vin'z Ice Cream & A24 \\
\hline 25. & Whyn*t Coffee \& Pastry & A25 \\
\hline
\end{tabular}

Kriteria yang digunakan dalam sistem pendukung keputusan memiliki unit perhitungan tidak pasti, sehingga membuat nilai yang diperoleh tidak dapat dihitung dengan perhitungan skala unit yang sama. Untuk itu diperlukan preferensi format untuk setiap kriteria yang ada, termasuk preferensi untuk kriteria bobot yang digunakan dalam proses menghasilkan alternatif rekomendasi restoran. Format preferensi pada sistem pendukung keputusan adalah sebagai berikut:

1. Kriteria harga dibagi menjadi 4 angka fuzzy yaitu sangat mahal, mahal, cukup murah dan murah. Angka fuzzy akan dikonversi ke angka crips dengan rentang nilai yang dapat dilihat pada Tabel 2.

Tabel 2. Harga

\begin{tabular}{|c|c|c|}
\hline Range Value & Fuzzy Number & Value \\
\hline $0-2$ & Sangat Mahal & 0.25 \\
\hline $3-5$ & Mahal & 0.5 \\
\hline $6-7$ & Cukup Murah & 0.75 \\
\hline $8-10$ & Murah & 1 \\
\hline
\end{tabular}

2. Kriteria rating dibagi menjadi 4 angka fuzzy yaitu sangat rendah, rendah, cukup tinggi dan tinggi. Angka fuzzy akan dikonversikan ke angka crips dengan rentang nilai yang dapat dilihat pada Tabel 3 .

Tabel 3. Rating

\begin{tabular}{|c|c|c|}
\hline Range Value & Fuzzy Number & Value \\
\hline $0-2$ & Sangat Rendah & 0.25 \\
\hline $3-5$ & Rendah & 0.5 \\
\hline $6-7$ & Cukup Tinggi & 0.75 \\
\hline $8-10$ & Tinggi & 1 \\
\hline
\end{tabular}

3. Kriteria kapasitas dibagi menjadi 4 angka fuzzy yaitu kecil, sedang, cukup besar dan besar. Angka fuzzy akan dikonversikan ke angka crips dengan rentang nilai yang dapat dilihat pada Table 4.

Tabel 4. Kapasitas

\begin{tabular}{|c|c|c|}
\hline Range Value & Fuzzy Number & Value \\
\hline $0-2$ & Kecil & 0.25 \\
\hline $3-5$ & Sedang & 0.5 \\
\hline $6-7$ & Cukup Besar & 0.75 \\
\hline $8-10$ & Besar & 1 \\
\hline
\end{tabular}

4. Kriteria jarak dibagi menjadi 3 angka fuzzy yaitu jauh, sedang dan dekat. Angka fuzzy akan 
dikonversikan ke angka crips dengan rentang nilai yang dapat dilihat pada Table 5 .

Tabel5. Jarak

\begin{tabular}{|c|c|c|}
\hline Range Value & Fuzzy Number & Value \\
\hline $\begin{array}{c}0 \mathrm{~km}=>\text { Value } \\
3 \mathrm{~km}\end{array}$ & Far & 0.75 \\
\hline $\begin{array}{c}3 \mathrm{~km}=>\text { Value }< \\
6 \mathrm{~km}\end{array}$ & Sufficient & 0.5 \\
\hline Value $=>6 \mathrm{~km}$ & Near & 0.25 \\
\hline
\end{tabular}

\subsection{Perancangan Proses}

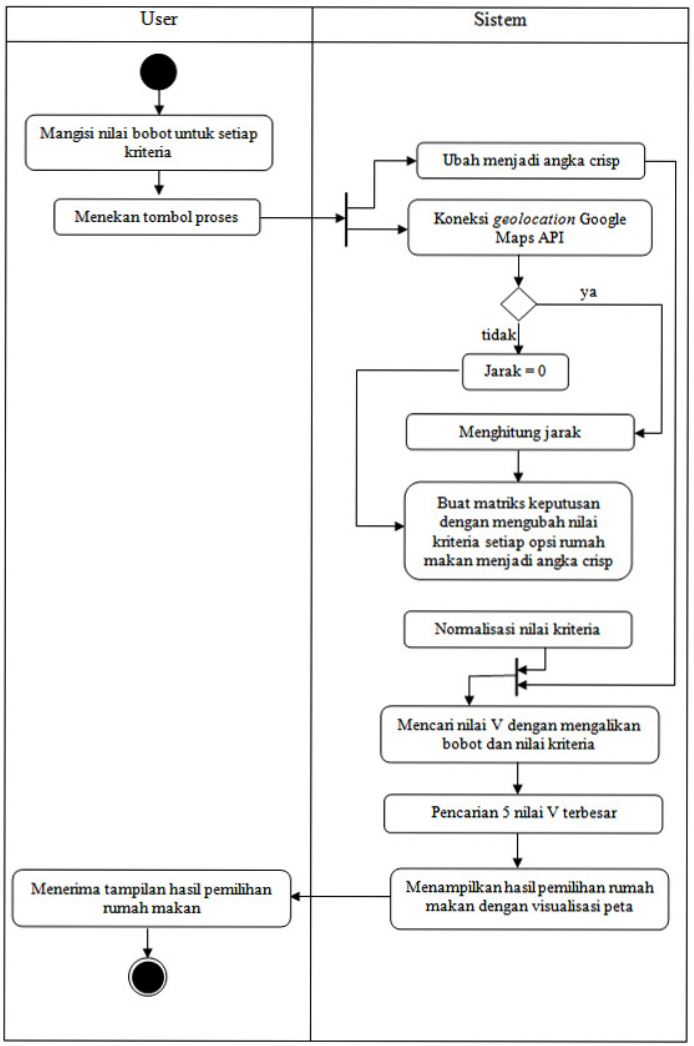

Gambar 5. Diagram Aktifitas Proses SAW

Langkah-langkah yang dilakukan dalam menerapkan metode SAW untuk pemilihan alternatif rumah makan terbaik, yaitu :

1. Menentukan kriteria-kriteria yang akan dijadikan acuan dalam pngambilan keputusan.

2. Menentukan range untuk merubah nilai bobot dan kriteria menjadi angka crisp.

3. Mengubah nilai bobot dan kriteria menjadi angka crisp.

4. Melakukan normalisasi nilai kriteria dengan membagi nilai dengan nilai kriteria terbesar.

5. Hasil akhir diperoleh dari proses perangkingan yaitu hasil penjumlahan dari perkalian matriks ternormalisasi dengan bobot yang telah diubah menjadi angka crisp.

Diagram aktifitas proses SAW sistem dapat dilihat pada gambar 5. Contoh kasus, diambil tiga sample rumah makan yaitu kedai dimsum, kedai kopi nusantara, dan kedai sabindo. Data dapat dilihat pada tabel 4.3. Kemudian diinputkan bobot harga 5 , rating 8 , kapasitas 6 , dan jarak 2 . Jarak dihitung dari titik 0 koordinat user yaitu Fakultas MIPA Universitas Mulawarman sampai dengan titik koordinat alternatif rumah makan.

Tabel 6 Data Rumah Makan

\begin{tabular}{|l|c|c|c|c|}
\hline Alternatif & Harga & Rating & Kapasitas & Jarak \\
\hline $\begin{array}{l}\text { Kedai } \\
\text { Dimsum }\end{array}$ & 7 & 7 & 5 & $\begin{array}{c}1.34 \\
\mathrm{~km}\end{array}$ \\
\hline $\begin{array}{l}\text { Kedai } \\
\text { Kopi } \\
\text { Nusantara }\end{array}$ & 6 & 6 & 6 & $\begin{array}{c}4.45 \\
\mathrm{~km}\end{array}$ \\
\hline $\begin{array}{l}\text { Kedai } \\
\text { Sabindo }\end{array}$ & 6 & 7 & 6 & $\begin{array}{c}2.35 \\
\mathrm{~km}\end{array}$ \\
\hline
\end{tabular}

Tahap pertama adalah menentukan range atau aturan yang menjadi dasar untuk mengubah nilai kriteria dan nilai bobot menjadi angka crisp.

Tahap kedua mengubah bobot menjadi angka crisp dan membuat tabel decision matrix untuk alternatif rumah makan yaitu mengubah nilai kriteria menjadi angka crisp. Berdasarkan aturan perubahan angka crisp, nilai bobot harga menjadi 0,5 nilai bobot rating menjadi 1 , nilai bobot kapasitas menjadi 0,75 dan nilai bobot jarak menjadi 0,25. Tabel decision matrix alternatif rumah makan dapat dilihat pada tabel 7.

Tabel 7. Decision Matrix Alternatif Rumah Makan

\begin{tabular}{|l|c|c|c|c|}
\hline Alternatif & Harga & Rating & Kapasitas & Jarak \\
\hline $\begin{array}{l}\text { Kedai } \\
\text { Dimsum }\end{array}$ & 0.75 & 0.75 & 0.5 & 0.75 \\
\hline $\begin{array}{l}\text { Kedai } \\
\text { Kopi } \\
\text { Nusantara }\end{array}$ & 0.75 & 0.75 & 0.75 & 0.5 \\
\hline $\begin{array}{l}\text { Kedai } \\
\text { Sabindo }\end{array}$ & 0.75 & 0.75 & 0.75 & 0.75 \\
\hline
\end{tabular}

Tahap ketiga yaitu melakukan normalisasi dari decision matrix, penjabaran dapat dilihat pada tabel 8.

Tabel 8. Normalisasi Matrix

\begin{tabular}{|l|c|c|c|c|}
\hline Alternatif & Harga & Rating & $\begin{array}{c}\text { Kapasi } \\
\text { tas }\end{array}$ & Jarak \\
\hline Kedai & $0.75 / 0.7$ & $0.75 / 0.7$ & $0.5 / 0.75$ & $0.75 / 0$. \\
Dimsum & $5=1$ & $5=1$ & $=0.67$ & $75=1$ \\
\hline Kedai & $0.75 / 0.7$ & $0.75 / 0.7$ & $0.75 / 0.7$ & $0.5 / 0.7$ \\
Kopi & $5=1$ & $5=1$ & $5=1$ & $\begin{array}{c}5= \\
\text { Nusantara }\end{array}$ \\
& & & 0.67 \\
\hline Kedai & $0.75 / 0.7$ & $0.75 / 0.7$ & $0.75 / 0.7$ & $0.75 / 0$. \\
Sabindo & $5=1$ & $5=1$ & $5=1$ & $75=1$ \\
\hline
\end{tabular}

Tahap keempat dilakukan perankingan atau mencari nilai $\mathrm{V}$ dengan cara menjumlahkan perkalian bobot dan kriteria.

1. Kedai Dimsum

$\mathrm{V}=(0.5 \times 1)+(1 \times 1)+(0.75 \times 0.67)+(0.25$

$\mathrm{x} 1)=2.25$

2. Kedai Kopi Nusantara

$\mathrm{V}=(0.5 \times 1)+(1 \times 1)+(0.75 \times 1)+(0.25 \times$ $0.67)=2.41$

3. Kedai Sabindo 
$\mathrm{V}=(0.5 \times 1)+(1 \times 1)+(0.75 \times 1)+(0.25 \times$

1) $=2.5$

Dari hasil tersebut dapat disimpulkan bahwa alternatif rumah makan terbaik adalah Kedai Sabindo dengan $\mathrm{V}=2.5$.

\subsection{Perancangan Sistem}

Perancangan sistem adalah rencana sistematis dalam proses pengembangan sistem setelah memiliki data yang cukup untuk menunjang kegiatan pengembangan sistem. Perancangan sistem ini menggunakan diagram UML yaitu use case diagram.Terdapat tiga level hak pengguna pada sistem ini yaitu admin, operator dan user.

Gambaran diagram use case sistem untuk user dapat dilihat pada Gambar 6.

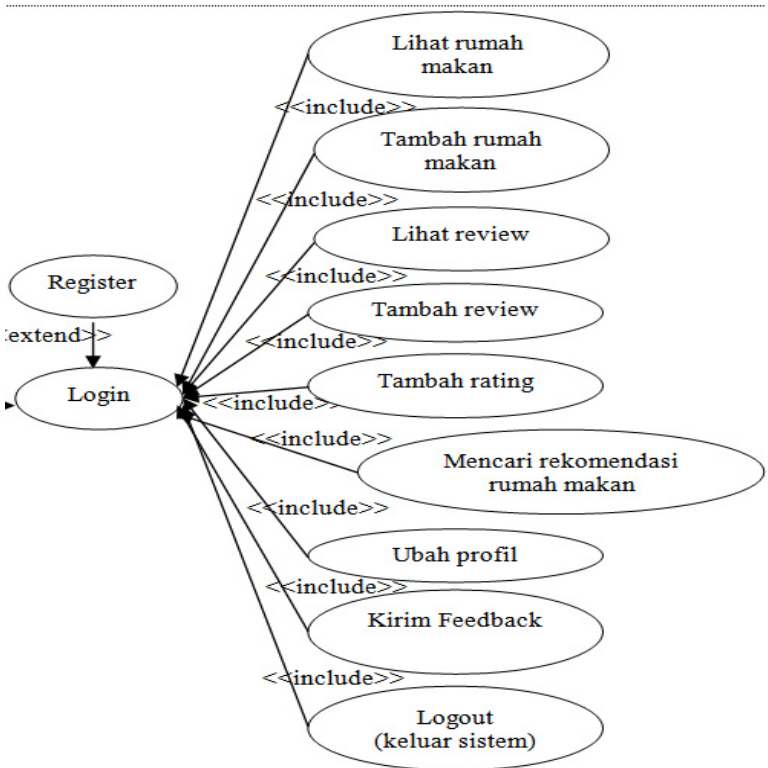

Gambar 6. Use Case Diagram Level User

User berperan dalam melakukan penambahan data rumah makan, rating dan review. Selain itu user dapat melihat informasi rumah makan, rating, maupun review. User diberi fasilitas untuk merubah profilnya, mengirim feedback, mencari rekomendasi rumah makan dan keluar dari sistem.

Level admin berfungsi manajemen rating dan review, manajemen user dan admin, melihat feedback dari user, dan manajemen data rumah makan yaitu menambah, mengedit, menghapus, dan memverifikasi rumah makan yang ditambahkan oleh user. Level operator memiliki fungsi yang sama dengan level admin hanya saja pada level operator tidak diberi hak untuk melakukan manajemen admin. Level user digunakan oleh pengunjung website yang ingin mendapatkan rekomendasi rumah makan, menambah data rumah makan, mengirim review, memberikan rating dan mengirim feedback. Halaman user dibangun berbasis Android Hybrid sedangkan halaman admin dan operator dibangun berbasis website.

Admin berperan dalam melakukan manajemen data rumah makan yang meliputi tambah data, edit data, dan memverifikasi data rumah makan. Admin juga berperan dalam melakukan manajemen review dan rating yaitu hapus data, manajemen user yaitu hapus user, manajemen admin yang meliputi tambah admin, edit admin, hapus admin, ubah profil, dan melihat hasil feedback dari user. Gambaran diagram use case sistem untuk admin dapat dilihat pada Gambar 7.

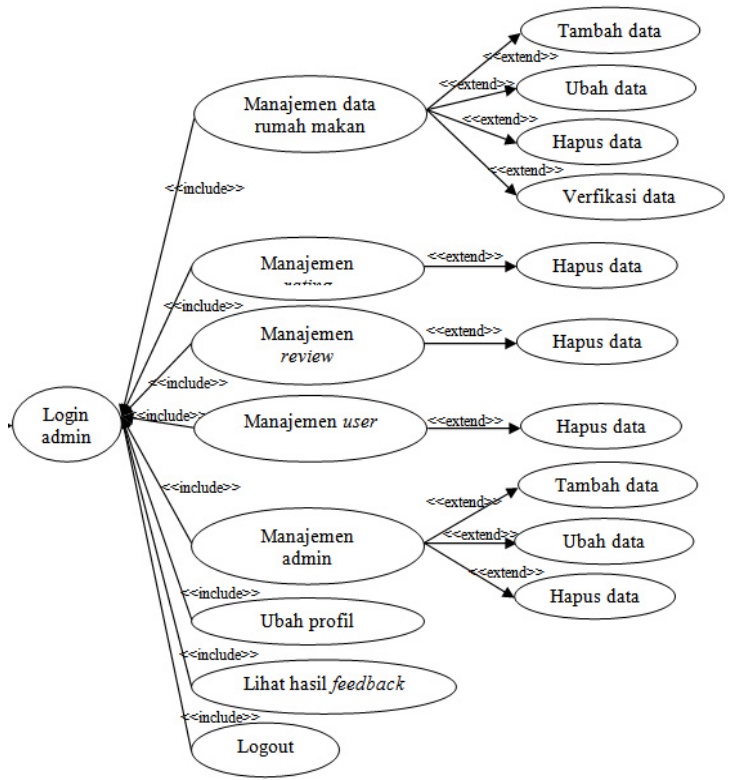

Gambar 7. Use Case Diagram Level Admin

Peran level operator sama dengan peran level admin hanya saja pada level operator tidak ada manajemen data admin. Operator hanya bisa mengubah profilnya sendiri. Gambaran diagram use case untuk level operator bisa dilihat pada Gambar 8.

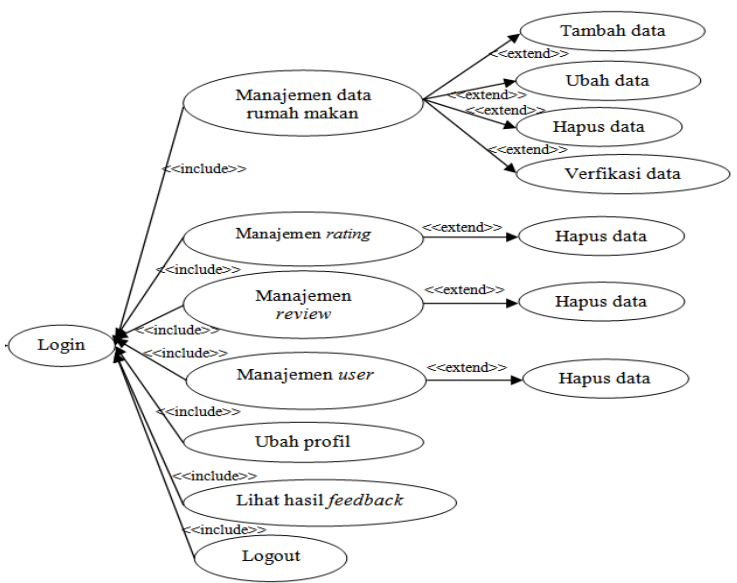

Gambar 8. Use Case Daigram Level Operator

\subsection{Implementasi Sistem}

Apabila sistem ini dieksekusi, maka halaman pertama yang tampil adalah halaman login yang merupakan pintu akses menuju aplikasi, pada halaman login terdapat pilihan mendaftar, menu ini disediakan bagi user yang belum memiliki akun. Halaman login sistem dapat dilihat pada gambar 9. 


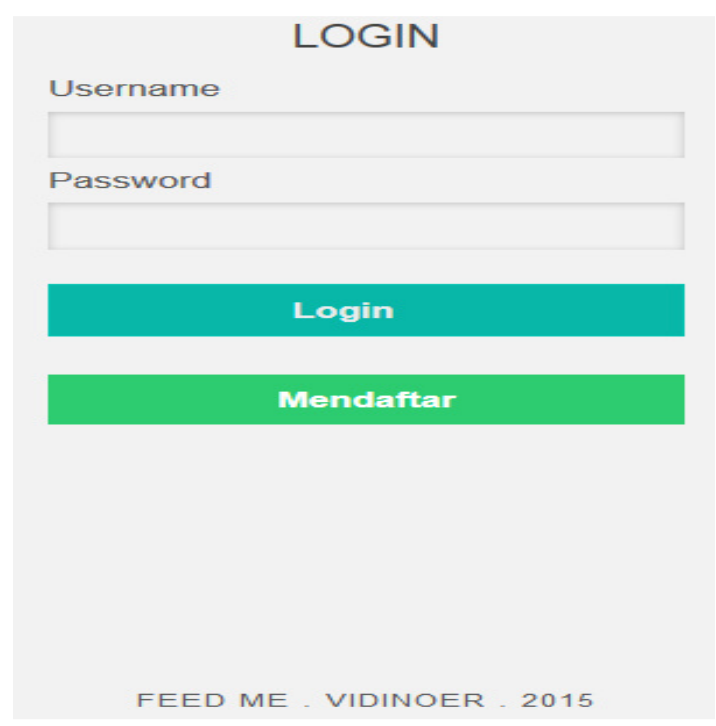

Gambar 9. Halaman Login

Setelah login, sistem akan menampilkan halaman utama yang berisi informasi rumah makan berupa foto rumah makan, nama rumah makan, rating berserta jumlah user yang memberi rating, alamat rumah makan, jumlah review, dan jam buka dan jam tutup rumah makan. Tampilan halaman utama dapat dilihat pada gambar 10.
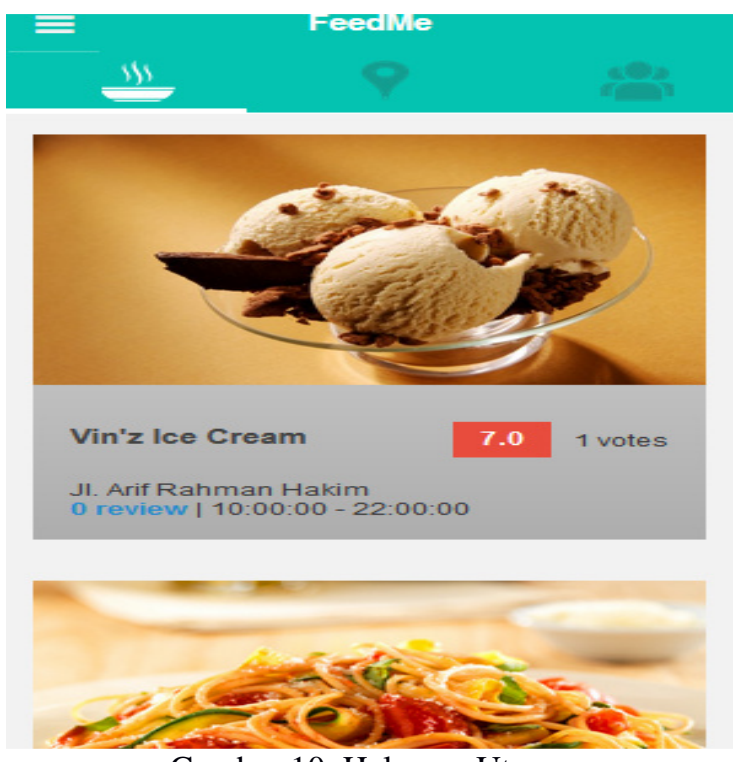

Gambar 10. Halaman Utama

Halaman rekomendasi rumah makan adalah halaman untuk memproses pemilihan rumah makan dengan metode SAW dapat dilihat pada gambar 11 .

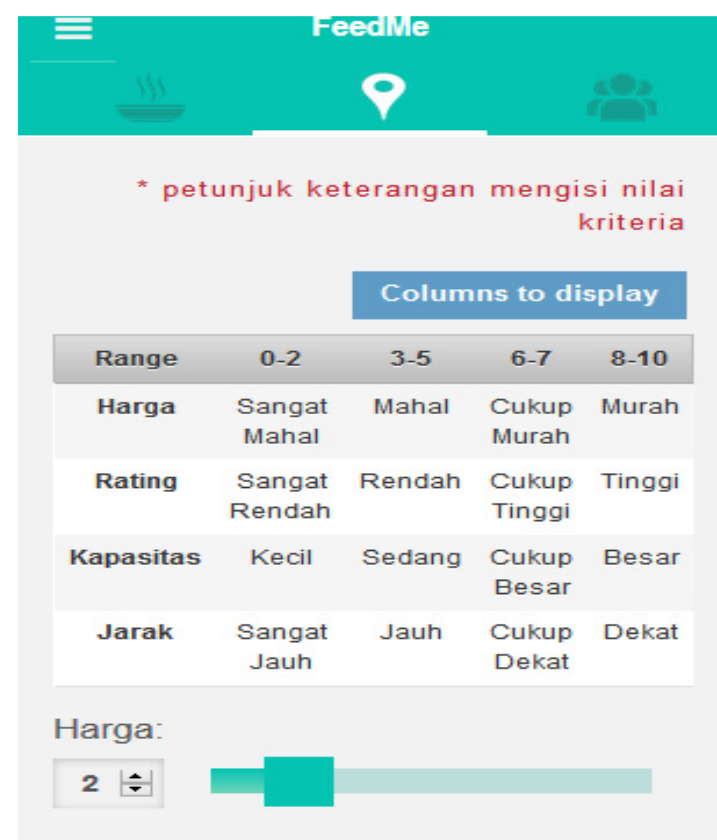

Gambar 11. Halaman Form Input Bobot

Halaman ini menampilkan keterangan untuk memasukan nilai bobot dalam bentuk tabel agar lebih mudah dipahami oleh user serta form berupa slider untuk menginput nilai bobot. Sebelum masuk ke halaman hasil, user diharuskan menginput nilai bobot dari angka 1-10 lalu menekan button cari, form input bobot dapat dilihat pada gambar 12 .

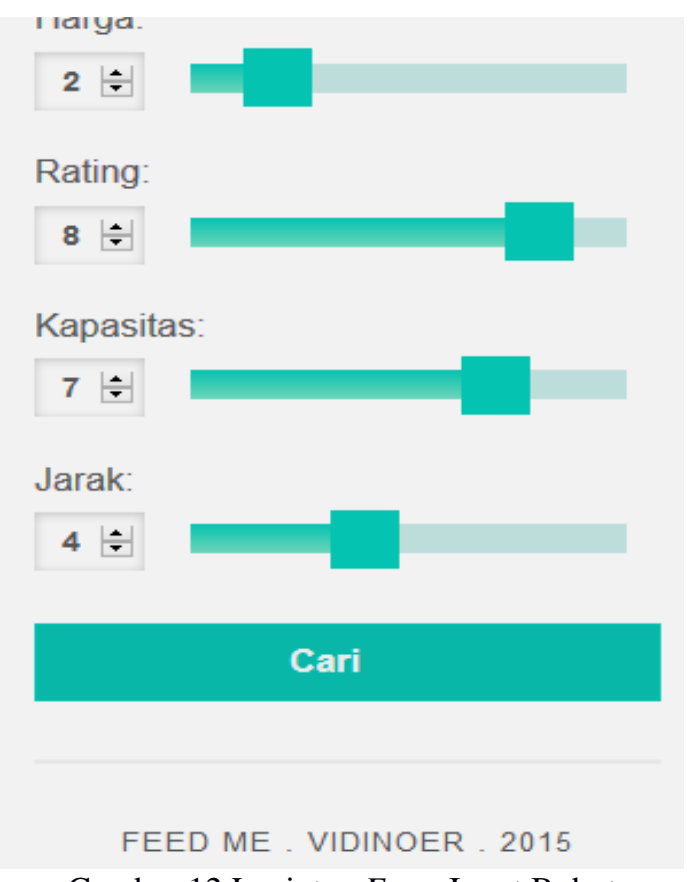

Gambar 12.Lanjutan Form Input Bobot

Setelah user mengklik button cari makan sistem akan melakukan proses perhitungan dengan metode SAW serta pencarian koordinat untuk menampilkan peta dan menghitung jarak. 
Sistem akan menampilkan hasil dengan visualisasi. Peta dilengkapi dengan mark untuk setiap rumah makan, mark direction and routing pada rumah makan yang merupakan hasil alternatif terbaik dan mark berupa badge nomor urut untuk lima alternatif terbaik. Gambar hasil rekomendasi peta dapat dilihat pada gambar 13 .

Gambar 13 menunjukan direction and routing terletak pada koordinat lokasi user dengan mark A dan lokasi alternatif terbaik berada pada mark B. Direction and routing memiliki fitur dragable atau koordinat lokasi dapat dipindah dengan menggeser mark direction and routing (mark A dan mark B) ke rumah makan yang dituju ataupun ketika GPS salah membaca koordinat lokasi user.
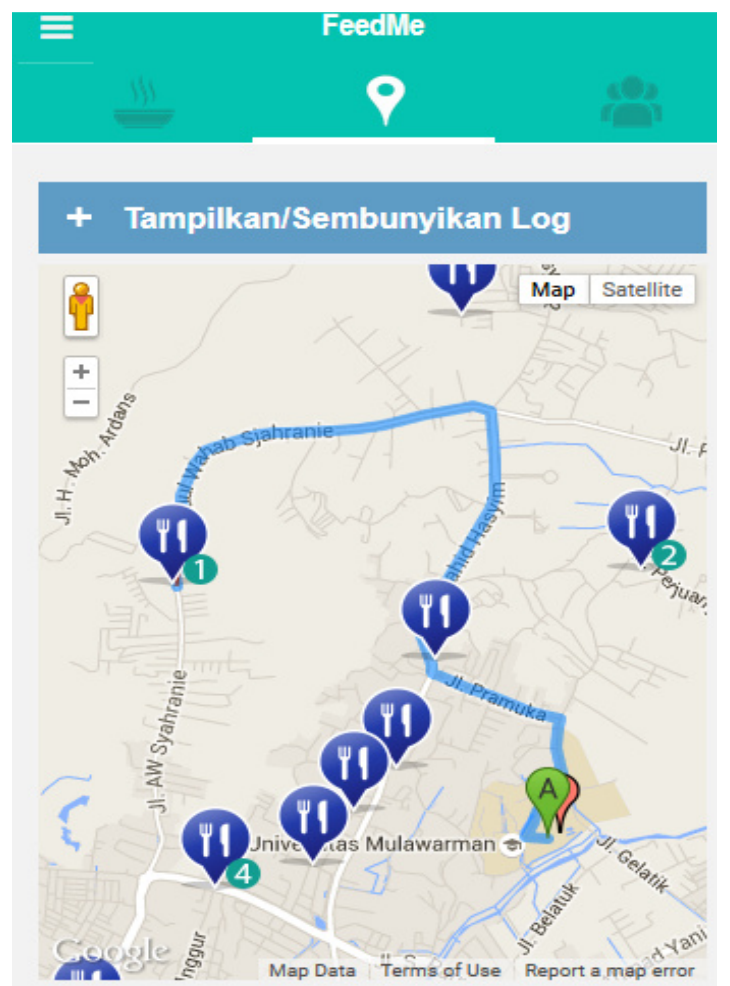

Gambar 13. Halaman Hasil Rekomendasi dengan Visualisasi Peta

Button log berguna untuk menampilkan atau menyembunyikan proses pemilihan rumah makan dengan metode SAW. Form proses pemilihan rumah makan dengan metode SAW dapat dilihat pada gambar 14.

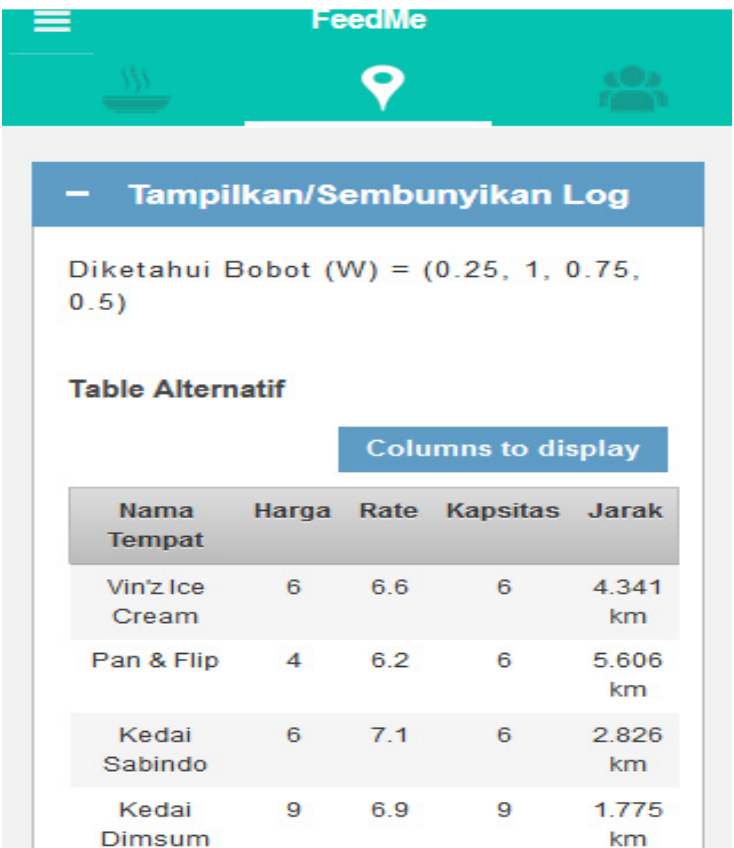

Gambar 14. Form Proses Pemilihan dengan Metode SAW

\section{KESIMPULAN}

Berdasarkan analisis dan pengujian yang dilakukan, maka kesimpulan yang dapat diambil adalah Penerapan metode SAW mampu memberikan opsi dalam memilih rumah makan, selain itu hybrid application dapat diterapkan untuk membangun aplikasi Android. Sistem ini sangat baik dikembangkan dengan teknologi API web servis dan dikembangkan ke platform lainnya seperti IOS.

\section{DAFTAR PUSTAKA}

[1]. Daihani, D. U. 2011. Komputerisasi Pengambilan Keputusan. Jakarta: Elexmedia Media Komputindo.

[2]. Fishburn, P. C. 1967. A Problem-based Selection of Multi-Attributr Decision Making Methods. New Jersey : Blackwell Publishing.

[3]. Kusrini. 2007. Konsep dan Aplikasi Sistem Pendukung Keputusan. Yogyakarta : ANDI.

[4]. Kusumadewi, S., Hartati, S., Harjoko, A., dan Wardoyo, R. 2206. Fuzzy .

[5]. Tun, Phyo Min. 2014. Choosing a Mobile Application Development Approach. Stamford International University, Thailand.

[6]. Turban, E., Aronson, J. E., dan Liang, T. P. 2005. Sistem Pendukung Keputusan dan Sistem Cerdas. Terjemahan Dwi Prabantini. Yogyakarta : Andi.

[7]. Wargo, J. (2012). PhoneGap Essential : Building Cross-platform Mobile Apps. United States: Addison-Wesley Professional 